\title{
Lumen
}

Selected Proceedings from the Canadian Society for Eighteenth-Century Studies

\section{The Treatment of Johnson's Shakespeare by Modern Editors: The Case of Henry $V$}

\section{Katherine N. West}

\section{Volume 13, 1994}

URI : https://id.erudit.org/iderudit/1012533ar

DOI : https://doi.org/10.7202/1012533ar

Aller au sommaire du numéro

\section{Éditeur(s)}

Canadian Society for Eighteenth-Century Studies / Société canadienne d'étude du dix-huitième siècle

ISSN

1209-3696 (imprimé)

1927-8284 (numérique)

Découvrir la revue

Citer cet article

West, K. N. (1994). The Treatment of Johnson's Shakespeare by Modern Editors: The Case of Henry V. Lumen, 13, 179-186. https://doi.org/10.7202/1012533ar 


\section{The Treatment of Johnson's Shakespeare by Modern Editors: The Case of Henry V}

Notes are often necessary, but they are necessary evils. ${ }^{1}$

- Samuel Johnson

Although Samuel Johnson embodied most of his editorial efforts in the notes to his 1765 edition of Shakespeare, the majority of critical writing on Johnson's edition centers on the Preface. Arthur Sherbo states that there has long 'persisted the misconception that Dr. Johnson's Preface is Dr. Johnson's edition of Shakespeare, or that his Preface and the General Observations are the edition.' He adds that the Preface 'has monopolized critical attention' although it was 'written last and printed less than two weeks before the edition was published. .' For example, Graham Parker's recent book Johnson's Shakespeare begins as follows: 'The most fitting preface to this discussion of Johnson's Shakespeare is Johnson's own; the extracts from the Preface to Shakespeare... present the reader with Johnson's leading propositions. ${ }^{3}$ Typically, references to Johnson's notes are employed only when they are useful for illustrating a concept from the Preface. The result of this is what Arthur Sherbo terms a 'phenomenon of present-day critics studying Johnson as a critic of Shakespeare without a single reference to a note in the edition. ${ }^{4}$

The unavailability of a complete text of Johnson's whole edition accounts for some of the neglect of Johnson's notes; as Shirley White Johnston points out, when most critics turn to Johnson's notes, 'they naturally reach for Arthur Sherbo's Johnson on Shakespeare volumes in the Yale edition. ${ }^{5}$ In addition to only printing brief textual lines, the Yale edition omits three types of notes from Johnson's edition. In the introduction, editor Arthur Sherbo states that comments are omitted if they are 'factual glosses of words or phrases [which] are obvious to any modern reader who has access to an annotated edition,' 'emendations or 
variant readings recorded from other editions, without comment by Johnson' and 'notes by other editors, printed without comment by Johnson. ${ }^{\prime 6}$ There are few instances in Shakespeare where any word or phrase can have a single obvious gloss, and the omission of these glosses affects the perception of Johnson by other critics in their commentaries if they rely on the Yale edition for a definitive source of Johnson's notes. More important, what this policy overlooks is the use of Johnson's notes for the study of Johnson, not just Shakespeare. The only way to achieve a complete reading of Johnson's Shakespeare is to go back to the first edition of 1765.

Although Johnson's notes are largely ignored by modern critics in favor of his Preface, perhaps a less overt but more damaging factor affecting Johnson's commentary is the neglect of modern Shakespearean editors to acknowledge Johnson when they adopt a reading which he had earlier suggested. Because of the failure to credit Johnson adequately, critics and scholars remain unaware of his contributions which are still prominent in modern editions.

In his Prolegomena for the Oxford Shakespeare, Ronald B. McKerrow explains the predicament of a twentieth-century editor when confronted with the history of editing Shakespeare: 'The question may well be asked: What do Rowe, Pope, and the rest of the eighteenth-century editors matter to us? Can we not ignore them and start afresh?' McKerrow asserts in a statement reminiscent of Johnson:

An editor's work necessarily involves interpretation, and a conscientious editor not only must feel reluctance in claiming as his own an interpretation (sometimes not very obvious) that he owes to his predecessors, but at the same time must, in doubtful cases, wish for their support.

McKerrow observes that neglecting previous editors is detrimental both to the reputations of these editors and to the progress of Shakespearean scholarship. He continues: 'To ignore the interpretation which these earlier editors placed on the many doubtful passages of Shakespearean text would, it seems to me, not only be a wrong to the pioneers in our study, but be a material loss to ourselves. ${ }^{77}$ Unlike the editors which I examine in this paper, Johnson himself was very conscientious about giving credit to previous editors. He states

What I have not given to another, I believed when I wrote it to be my own... if I am ever found to encroach upon the remarks of any other commentator, I am willing that the honour, be it more or less, should be transferred to the first claimant, for his right, and his alone, stands above dispute. ${ }^{8}$ 
The current relationship between Johnson and modern Shakespearean editions is appropriately described by Shirley White Johnston as a state of 'depreciation perennially given his editorship of the plays. ${ }^{9}$ There is a problematic relationship between the authority of Johnson's editorial decisions and their affinity with instinctive editorial practice. If Johnson was the first to put an obvious gloss of a line into print, is he entitled to credit even if the same interpretation could have been made by any intelligent scholar? Or are modern editors only indebted to Johnson for glosses or emendations which are the unique product of Johnson's efforts? Johnson's comments range from obvious explanations of lines, to ingenious explications of lines that modern editors still rely on for their editions. Are modern editors accountable for every interpretation that resembles Johnson's (or any other editor's, for that matter)? In the 1954 Arden edition of Henry $V$ edited by J. H. Walter and the more recent 1982 Oxford Henry $V$ edited by Gary Taylor, I will show that Johnson is neglected both when an editor glosses a line with the same actual words that Johnson uses and when an editor seems to rely on Johnson for an explanation of a line that is not obvious, if we could call the meaning of any line in Shakespeare obvious.

The only statement concerning previous editors in the Arden edition occurs at the conclusion of the introduction. J. H. Walter states that 'reference in the textual footnotes to earlier editions of Shakespeare is made by citing the name of the editor. ${ }^{10}$ Walter then lists earlier editions to which he refers, including Johnson's, but gives no criteria for when he credits Johnson and other editors and when he chooses not to.

The evidence in the Arden edition invites the conclusion that Johnson's contribution to Shakespearean scholarship on Henry $V$ consists of only an occasional emendation or explication. Johnson receives credit for eight textual emendations and four explanatory notes. However, upon closer examination, this edition owes more to Johnson than is acknowledged. When the two editions are compared, Johnson's influence looms silently among the textual notes. Time after time Walter and Johnson explain or define phrases using identical terms, but Johnson receives no credit for his contribution. The considerable number of similarities between Johnson's edition and the Arden edition is too substantial to be coincidental. Whether Walter was adhering to any unstated editorial principles or not, his treatment of Johnson's text contributes to the impression readers, scholars, and critics have of Johnson's edition.

To insure that this neglect of acknowledging Johnson is not an isolated case with this particular edition, an analysis of the Oxford edition 
confirms the general absence of credit to Johnson in twentieth-century editions. Gary Taylor cites Johnson several times in his introduction, as well as in his notes, but nevertheless there remain numerous passages with unacknowledged debts to Johnson. In a section entitled 'Editorial Procedures,' Taylor states: 'In the absence of even an antiquated Variorum edition of Henry $V$, one can hardly be positive that a particular editor was the undoubted first to propose or adopt a given emendation.' While Taylor asserts that 'the attributions in this edition go some way towards correcting the inadequacy of previous accounts,' he feels that 'the accuracy of such credits (or debits) means more to the vanity of editors than to the variety of readers.' One could hardly call accurately crediting Johnson a contribution to his vanity! Taylor then continues, 'I have tried to specify my borrowings from or disagreements with more recent editors; eighteenth- and nineteenth-century contributions generally remain unidentified.' He adds: 'Modern editors sometimes credit other modern editors with discoveries that go back two hundred years, or ignore earlier scholarship completely.' He concludes with the vague statement: 'I have therefore occasionally provided early attributions, for these or similar reasons. ${ }^{11}$ While Taylor seems to recognize the problem of assigning credit to individual editors for specific passages, his edition does little to rectify the situation.

Although there are several examples from these editions ranging from condemning to forgivable, because of limited space I have selected four representative cases to examine; other examples can be found in the Appendix. ${ }^{12}$ For Canterbury's line: 'Never came reformation in a flood,/With such a heady currance, scouring faults' (1.1.33-4), Johnson provides the following explanation: 'Alluding to the method by which Hercules cleansed the famous stables when he turned a river through them. Hercules still is in our authour's head when he mentions the Hydra.' The Arden editor comes to a strikingly similar conclusion about the meaning of this line: 'Possibly an allusion to the cleansing of the Augean stables by Hercules who diverted a river through them.' The Oxford editor has an analogous explication: 'Alluding to the cleansing of the Augean stables by Hercules, who diverted a river through them. ${ }^{13}$ Not only do both editors interpret the line as Johnson did, their explanations also employ several obvious verbal parallels.

In the second scene of act two, King Henry uses the phrase: 'Such, and so finely bolted, didst thou seem' (137). Johnson states that 'Boulted is the same with sifted, and has consequently the meaning of refined.' The Arden edition duplicates Johnson's interpretation: 'sifted (like flour), refined,' as does the Oxford edition with 'Sifted, refined,' but neither editor credits Johnson even though they both use his exact terms. ${ }^{14}$ 
Johnson glosses Pistol's line: 'Be merciful, great duke, to men of mould' (3.2.22) with the phrase: 'To men of earth, to poor mortal men.' Similarly, the Arden edition has 'men of earth, mere mortals,' and the Oxford has 'men (compounded) of earth, mere mortals. ${ }^{15}$ Although there are only minimal variations between Johnson and both of these editions, Johnson is not acknowledged.

Finally, for King Henry's line: 'The farced title running 'fore the king' (4.1.269), Johnson states that 'Farsed is stuffed.' Both the Arden edition and the Oxford edition define farced with the word 'stuffed,' but neither credits Johnson for this term. ${ }^{16}$

The evidence from both the Arden edition and the Oxford edition of Henry $V$ overwhelmingly supports the importance of Johnson's edition and its unacknowledged influence on modern editions. Many of Johnson's notes are quoted verbatim without credit, and others are paraphrased to arrive at the same meaning. Both instances demonstrate that Johnson's interpretation of Henry $V$ is closer to twentieth-century editions than editorial practices reveal. A re-examination of Johnson's notes on other plays would most likely expose several situations like Henry $V$, where a careful scrutiny of modern explications and interpretations would uncover substantial fragments of Johnson underneath the foundations of twentieth-century editions of Shakespeare.

\section{KATHERINE N. WEST}

University of Toronto

\section{Notes}

1 Samuel Johnson, ed., The Plays of William Shakespeare, 8 vols. (London, 1765), 1: lxix.

2 Arthur Sherbo, Samuel Johnson, Editor of Shakespeare, Illinois Studies in Language and Literature 42 (Urbana: University of Illinois Press, 1956), 46.

3 Graham Parker, Johnson's Shakespeare (Oxford: Clarendon Press, 1989), xi.

4 Sherbo 61.

5 Shirley White Johnston, 'From Preface to Practice: Samuel Johnson's Editorship of Shakespeare', Green Centennial Studies, ed. Paul J. Korshin (Charlottesville: University Press of Virginia, 1984), 250.

6 Arthur Sherbo, ed., Johnson on Shakespeare, Yale Edition of the Works of Samuel Johnson 7 (New Haven and London: Yale University Press, 1968), xlii.

7 Ronald B. McKerrow, Prolegomena for the Oxford Shakespeare (Oxford: Clarendon Press, 1939), 71-72. 
8 Johnson 1: lvi-lvii.

9 Johnston 250.

10 William Shakespeare, Henry V, ed. J. H. Walter (London: Methuen, 1954), xlvi.

11 William Shakespeare, Henry V, ed. Gary Taylor (Oxford: Clarendon Press, 1982), 78.

12 As there are too many instances to cite here where unacknowledged debts to Johnson occur in these two editions, I have provided representative examples in the Appendix below, as well as some examples where Johnson is credited to show the haphazard nature of these editorial decisions. I have also specified notes which are omitted from the Yale edition. References in the Appendix are cited by the page number of each edition, and lines from Shakespeare refer to those in the Arden edition.

13 Johnson 4: 364; Walter 10; Taylor 95.

14 Johnson 4: 393; Walter 43; Taylor 138.

15 Johnson 4: 408; Walter 61; Taylor 161.

16 Johnson 4: 442; Walter 104; Taylor 218.

\section{Appendix}

King Henry: 'That all the courts of France will be disturb'd/With chases' (1.2.265-6).

Johnson: 'a term at tennis' (378), not in the Yale edition.

Arden: 'points in tennis' (26).

Walter does not credit Johnson for this, but instead cites the editor of a tennis magazine for the explication: 'the note on scoring in tennis, I.ii.263, owes much to the information very kindly given me by $\mathrm{Mr}$. L.H.J. Dorey, Editor of Lawn Tennis and Badminton' (ix).

Exeter: 'He sends you this most memorable line' (2.4.88).

Johnson: 'This genealogy; this deduction of his lineage' (402).

Arden: 'pedigree, line of descent' (53).

Oxford: 'genealogical table' (151).

Chorus: 'O, do but think/You stand upon the rivage' (3.0.13-14).

Johnson: 'The bank or shore' (405), not in the Yale edition.

Arden: 'shore' (56).

Oxford: 'shore (poetic)' (155). 
King Henry: 'bend up every spirit/To his full height' (3.1.16).

Johnson: 'A metaphor from the bow' (406).

Arden: 'a metaphor that is derived from drawing a bow' (58).

Oxford: 'used originally of drawing a bow' (158).

Fluellen: 'I think a' will plow up all' (3.2.67).

Johnson: 'he will blow up all' (409), not in the Yale edition.

Arden: 'blow' (63).

Oxford: 'blow' (164).

Dauphin: 'The emptying of our fathers' luxury' (3.5.6).

Johnson: 'in this place, as in others, luxury means lust' (416), not in the Yale edition.

Arden: 'lust' (72).

Oxford: 'lust' (180).

Dauphin: 'Our scions, put in wild and savage stock' (3.5.7).

Johnson: 'Savage is here used in the French original sense, for silvan, uncultivated, the same with wild' (416).

Arden: 'uncultivated, wild' (72).

King Henry: 'All his senses have but human conditions' (4.1.104).

Johnson: 'Conditions are qualities' (437).

Arden: 'dispositions, qualities' (98).

Williams: 'Some upon their children rawly left' (4.1.143).

Johnson: 'without preparation, hastily, suddenly. What is not matured is raw' (438). Johnson also cites the same parallel reading as Walter and Taylor, Macbeth 4.3.26-8.

Arden: 'abruptly' (99).

Oxford: 'left abruptly, and unprovided for' (212).

King Henry: 'A gentleman of great sort' (4.7.139-40).

Johnson: 'High rank' (463).

Arden: 'rank, quality' (129).

Oxford: 'rank' (250).

Burgundy: 'which to reduce into our former favour' (5.2.63).

Johnson: 'Former appearance' (477), not in the Yale edition.

Arden: 'appearance' (145).

Oxford: 'appearance' (268). 
Examples where Johnson is credited:

Fluellen: '... is digt himself four yard under the countermines' (3.2.66).

Arden: "'has digged himself countermines four yards under the mines" (Johnson)' (63).

King Henry: 'Peace to this meeting, wherefore we are met!' (5.2.1).

Arden: "'Peace, for which we are here met, be to this meeting" (Johnson)' (142).

Canterbury: 'Setting endeavor in continual motion;/To which is fixed, as an aim or butt,/Obedience' (1.2.184-5).

Oxford: " The sense is, that all endeavor is to terminate in obedience" (Johnson)' (110). 